\title{
SOUTH AFRICA AND THE WAR AGAINST JAPAN 1941-1945
}

\author{
Cdr W.M. Bisset \\ South African Naval Museum, Simon's Town
}

Although South Africa was never attacked by Japan during the Second World War, the threat was considered to be so great that one of our most distinguished soldiers, Brigadier (later Major General) W.H. Evered Poole was recalled from the Western Desert on 26 May 1942 and appointed Fortress Commander at The Castle in Cape Town.

South Africa's published Official Histories of the Second World War contain few details of South Africans who served in the Far East. Commander H.R. Gordon-Cumming's unpublished Official History of the SA Naval Forces in the Second World War 1939-1945 includes narratives of the two South African ships which served in the Far East, HMSAS BARBRAKE and HMSAS NATAL, and HMS
Since no recipient could receive both stars, the total number of South African servicemen who received awards for their service in the Far East is 2404.

An official press release authorized by Commodore J. Dalgleish, Director of the SANF, dated 22 May 1945 , stated that there were more than 2000 South Africans seconded to the Royal Navy serving in the Far East.

Apart from the SANF ships' companies mentioned above, all our naval personnel were seconded to the Royal Navy and constituted the largest group of South African servicemen in the Far East. A number of South Africans in the Merchant Navy

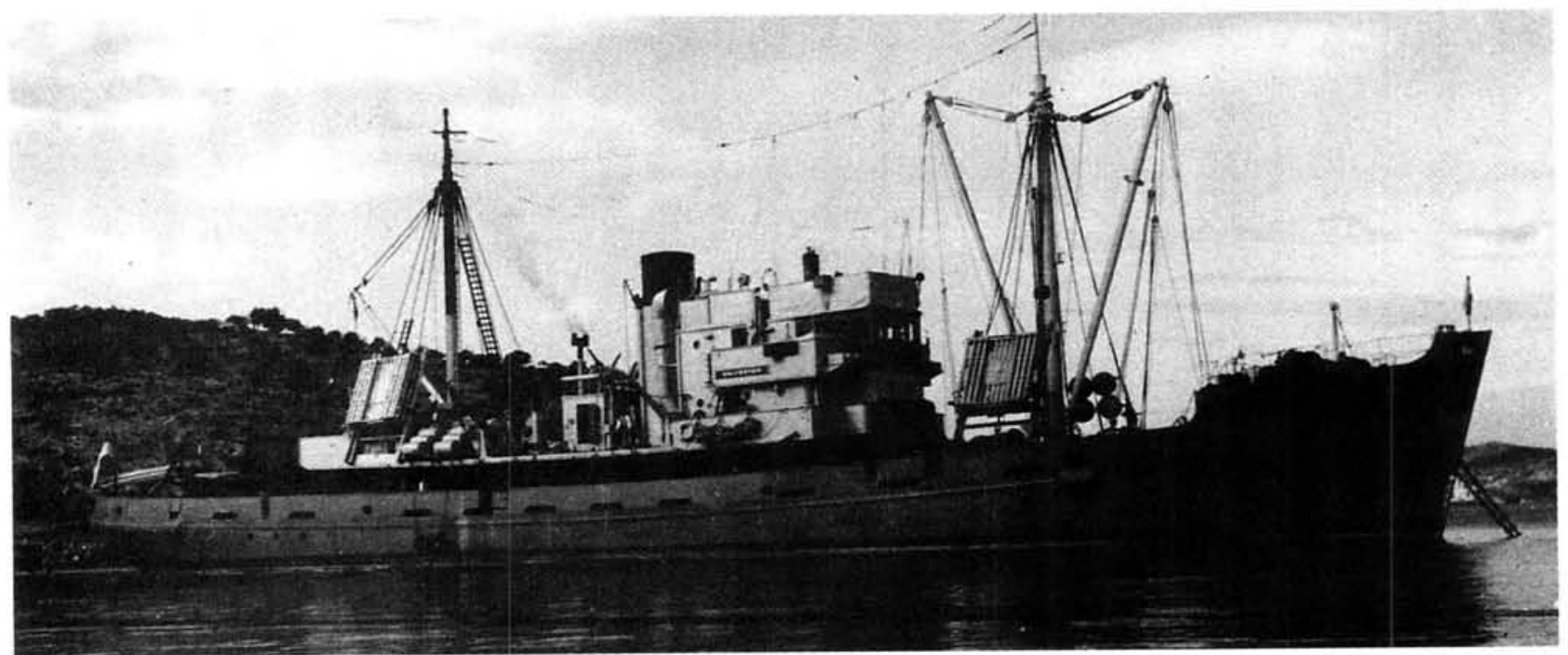

HMS SALVESTOR, a King Salvor class Ocean salvage vessel, was manned by a South African crew.

(SA National Museum of Military History)

TEVIOT and HMS SALVESTOR which were manned by the South African Naval Force (SANF).

The war medal research work carried out by the late Mr D.R. Forsyth reveals how many South African servicemen received campaign stars or clasps for service in the Far East:

$\begin{array}{lr}\text { Pacific Star } & 472 \\ \text { Pacific Clasp } & 295 \\ \text { Burma Star } & 1932 \\ \text { Burma Clasp } & 151\end{array}$

also served there, but it is not certain whether their details were included in Forsyth's statistics.

Our naval personnel were in the thick of the fighting when a Japanese victory seemed near. Ordinary Seaman W.D. Adamson was lost with HMS REPULSE on 10 December 1941 and it is probable that there were other seconded South Africans aboard who survived.

On 1 March 1942 the York class cruiser HMS EXETER and 'E' class destroyer HMS ENCOUNTER 


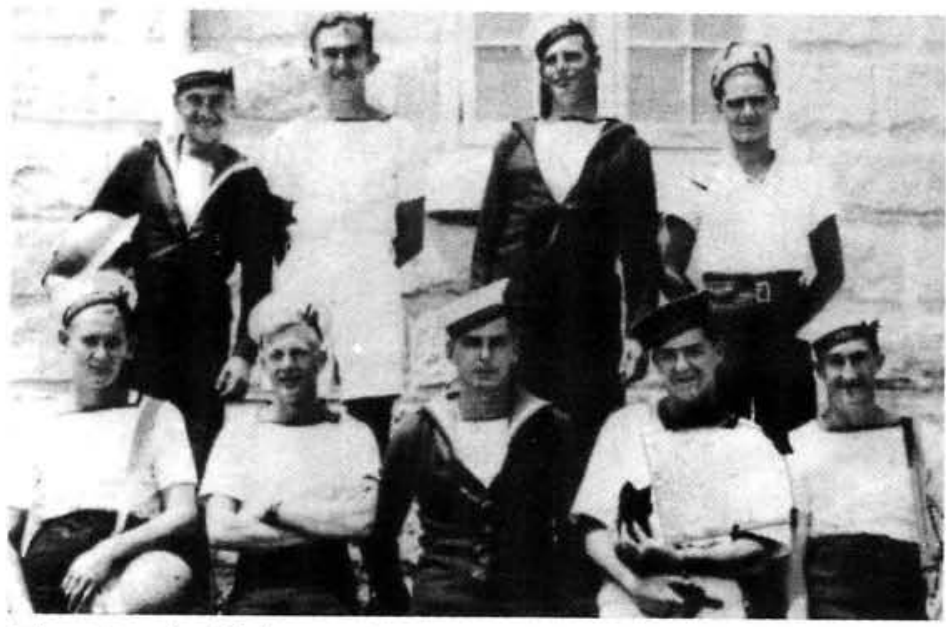

The South African who served in HMS ENCOUNTER, photographed at Malta in May 1941 with their South African mascot - a kitten named Smuts. The Ship was sunk in the battle of the Java Sea on 1 March 1942.

were lost with most of the Allied Striking Force in the battle of the Java Sea in a gallant fight against a superior Japanese force.

A South African survivor from HMS EXETER, a young seaman, later witnessed the explosion of one of the atomic bombs while he was a prisoner of war in Japan. Another South African survivor of the battle of the Java Sea, Able Seaman Nelson Hefferman from Port Elizabeth who had served in HMS ENCOUNTER, later died in a Japanese prisoner-of-war camp. His autographed bamboo mug has survived and is now on display with his medals in the SA Naval Museum in Simon's Town.

The seconded South Africans serving in the Danae class cruiser HMS DRAGON narrowly escaped being sunk in the battle of the Java Sea and one of them, Eric Little, became the first South African to write a book about his life in the Royal Navy which he entitled most appropriately The Luck of HMS DRAGON.

On Easter Sunday, 5 April 1942, 25 seconded South African sailors were lost when the Kent class cruiser
HMS CORNWALL was sunk by the Japanese. Another 16 of them were lost in the Norfolk class cruiser HMS DORSETSHIRE which was sunk on the same day.

The Japanese aircraft machine-gunned the survivors in the water. Nonetheless many of them were rescued after the $1^{\circ}$ day ordeal which most had spent in the sea as space in lifeboats or rafts was limited and reserved for the sick and wounded. Two South Africans were mentioned in despatches: Lieutenant G.M. Berlyn of HMS DORSETSHIRE who swam from one group of survivors to another to keep their morale up, and Sick Berth Attendant C.W. Thorne who was honoured for "his devoted services in the care of the wounded when HMS DORSETSHIRE was lost".

Another 16 seconded South African sailors were lost in the aircraft carrier HMS HERMES which was sunk off Ceylon on 9 April 1942. A wartime booklet lists the SA Naval Forces as one of the five navies which liberated Burma. Although the South Africans in the Fairmile Motor Launches which served with great gallantry in the Burmese chaungs were all seconded; their motor launches had been built in South Africa. Many of the ratings who manned them had served in HMS SHROPSHIRE in the first Russian Convoy codenamed Dervish. One of them, Eugene Kimble, has recently published his war memoirs which are entitled The Forgotten Few.

In addition to the seconded South Africans, many other South Africans served in the Far East in British Forces and in the Indian Army in which a number had made their careers as officers.

Major General E.C.R. 'Bobs' Mansergh commanded the 5th Indian Division in Burma. He ended his long and distinguished career as a full general, G.C.B., and Master Gunner of the Royal Artillery.

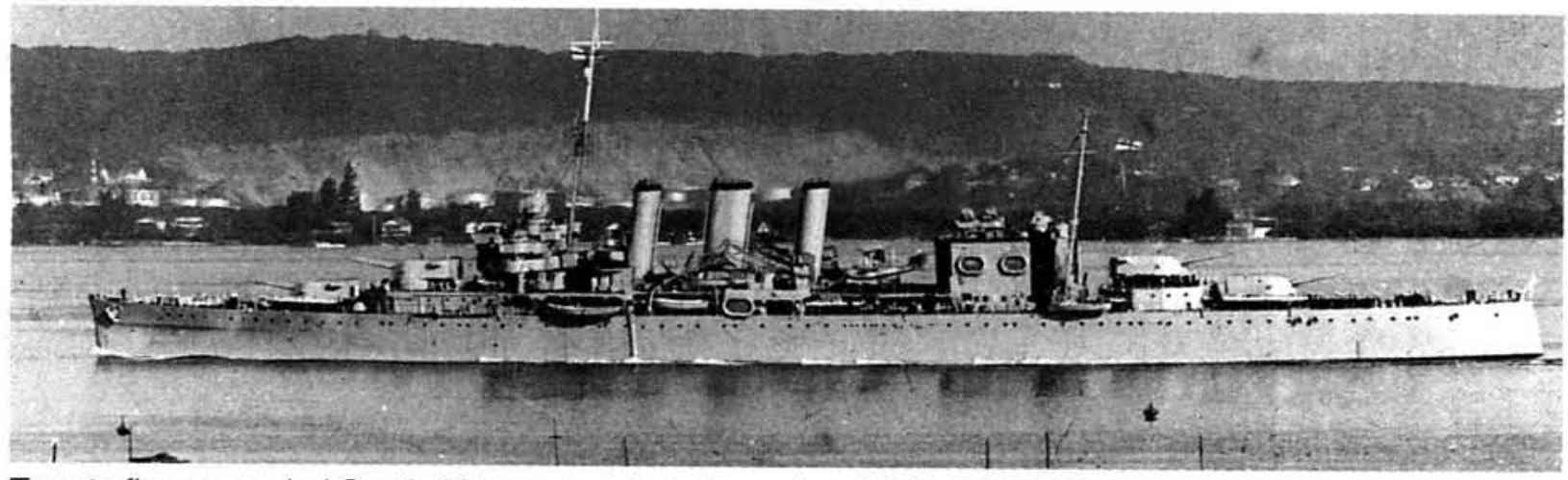

Twenty five seconded South Africans lost their lives when HMS CORNWALL was sunk on 5 April 1942.

(Courtesy of Mr G. Upton) 


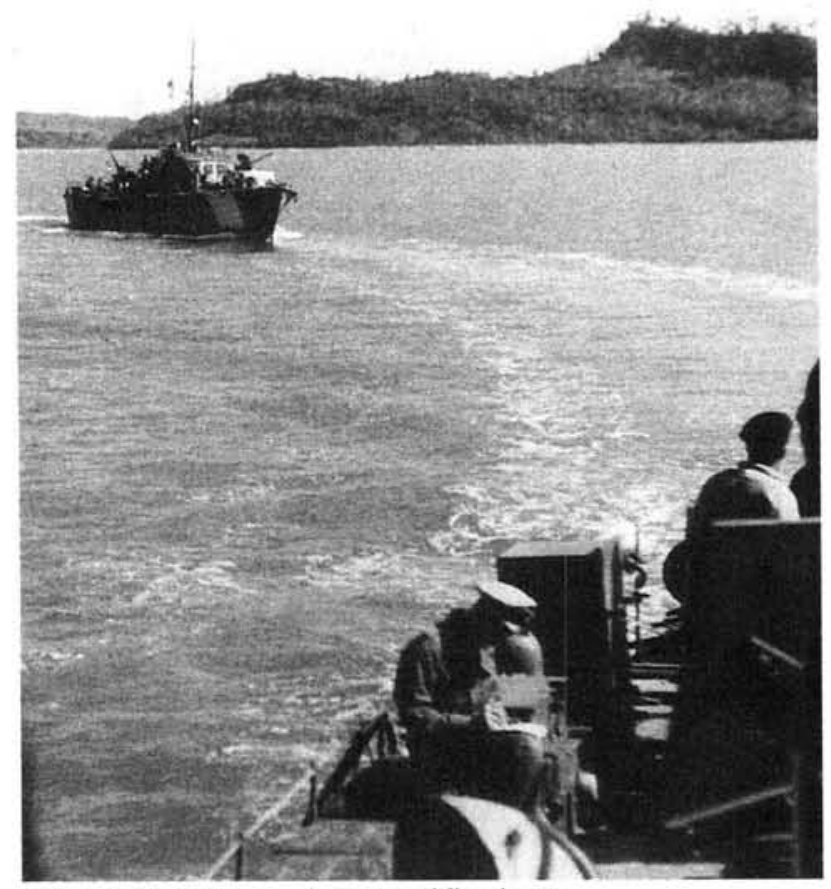

MLs 438, 441, and 477 at Kiuakpyu.

(Courtesy of Mr M.E. Bartholomew)

Another South African, Major Harold LangfordBrowne, a wartime volunteer, was second-in-command of the legendary Elephant Company of the Royal Indian Engineers. He was awarded the M.B.E. and was twice mentioned in despatches. His gallant exploits are described by Lieutenant Colonel J.H. Williams in his book Elephant Bill.
South African officers seconded to the Royal Marines served with distinction in the Far East. Most of them had landed in France on D-Day and served in the campaign to liberate North West Europe which followed. Major Gideon Jacobs, then 23 years old, was awarded the O.B.E. for his services in Sumatra after the Japanese surrender which are described in his book Prelude to the Monsoon.

Another distinguished South African Royal Marine officer, Captain Denys Ranger, M.B.E., M.C. was the only non-SANF South African recipient of the Pacific Star.

Very few South African Army officers appear to have served in the Far East. One of them was Major General Kenneth Ray, C.B., C.B.E., D.S.O. who was Chief Engineer, South East Asia Command from late in 1944 until July 1945.

South African Air Force and SA Naval Forces Fleet Air Arm pilots also served with distinction in the Far East. The most remarkable South African Air Force officer was Major General J.T. Durrant, C.B., D.F.C., who is believed to have been the youngest general officer in the British Forces during the Second World War and was Air Officer Commanding, 231 Heavy Bomber Group, Royal Air Force.

At the Japanese surrender on board USS MIS-

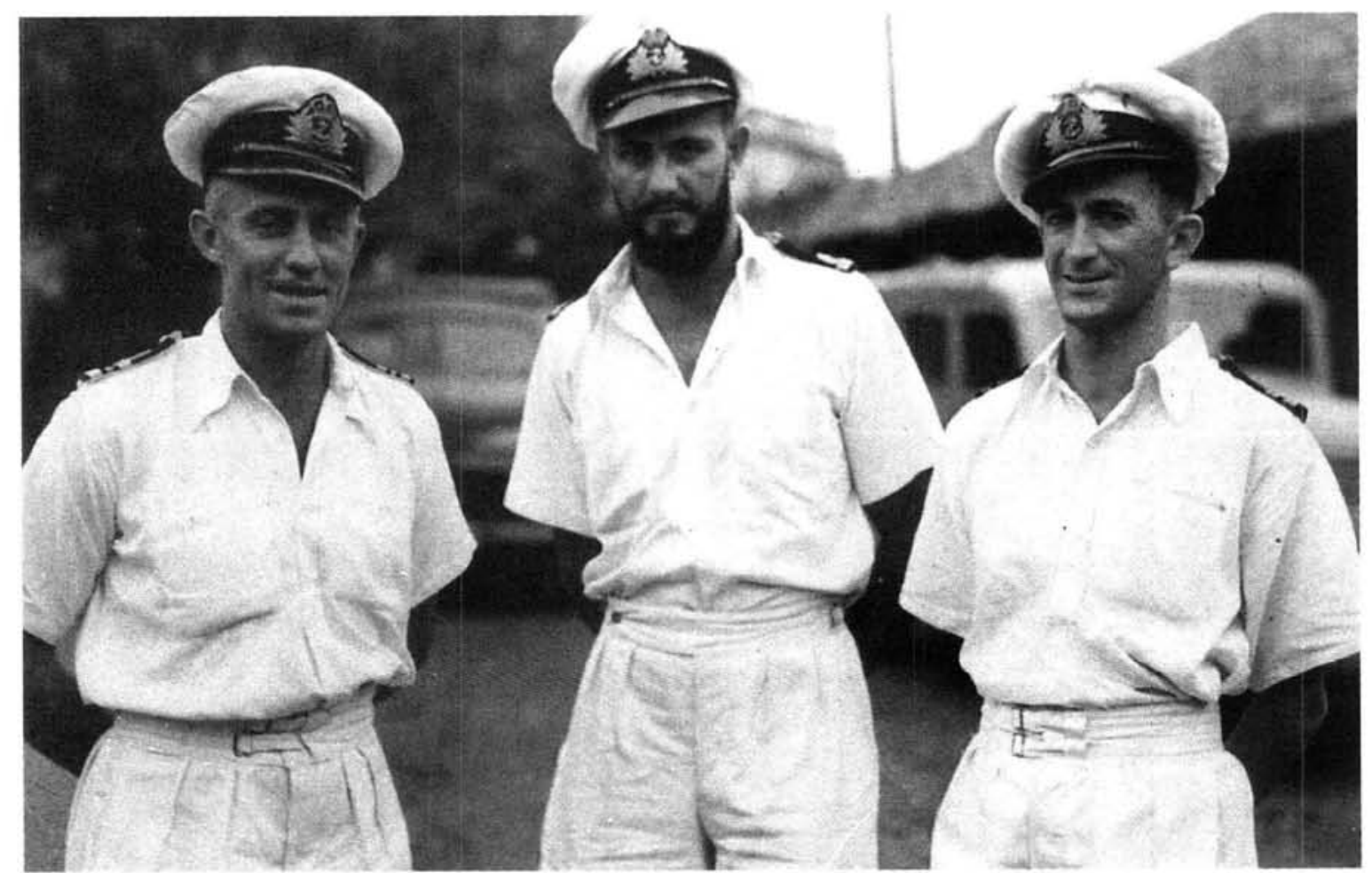

Three South African Naval Forces officers who served in Burma: Lt Cdr A.G. Milne, DSC, Senior Officer 49th ML Flotilla; S Lt H.G. Twine; and Lt R.L.J. Williams, DSC.

(Courtesy of Mr M.E. Bartholomew) 
SOURI on 2 September 1945, South Africa was represented by Commander A.P. Cartwright, SANF. Other South Africans present on VJ-Day included Commander C.P. Norton, RN, Able Seaman Harold Bruce in HMS DUKE OF YORK, Lieutenant R.E. Taylor in HMS KING GEORGE V and sub-lieuten- ants C.G.G. Goodwin and E.S.W. Simpson in HMS DERG.

South Africa recalls with pride her part in the $\mathrm{Pa}$ cific War and the great sacrifices made by her gallant servicemen.

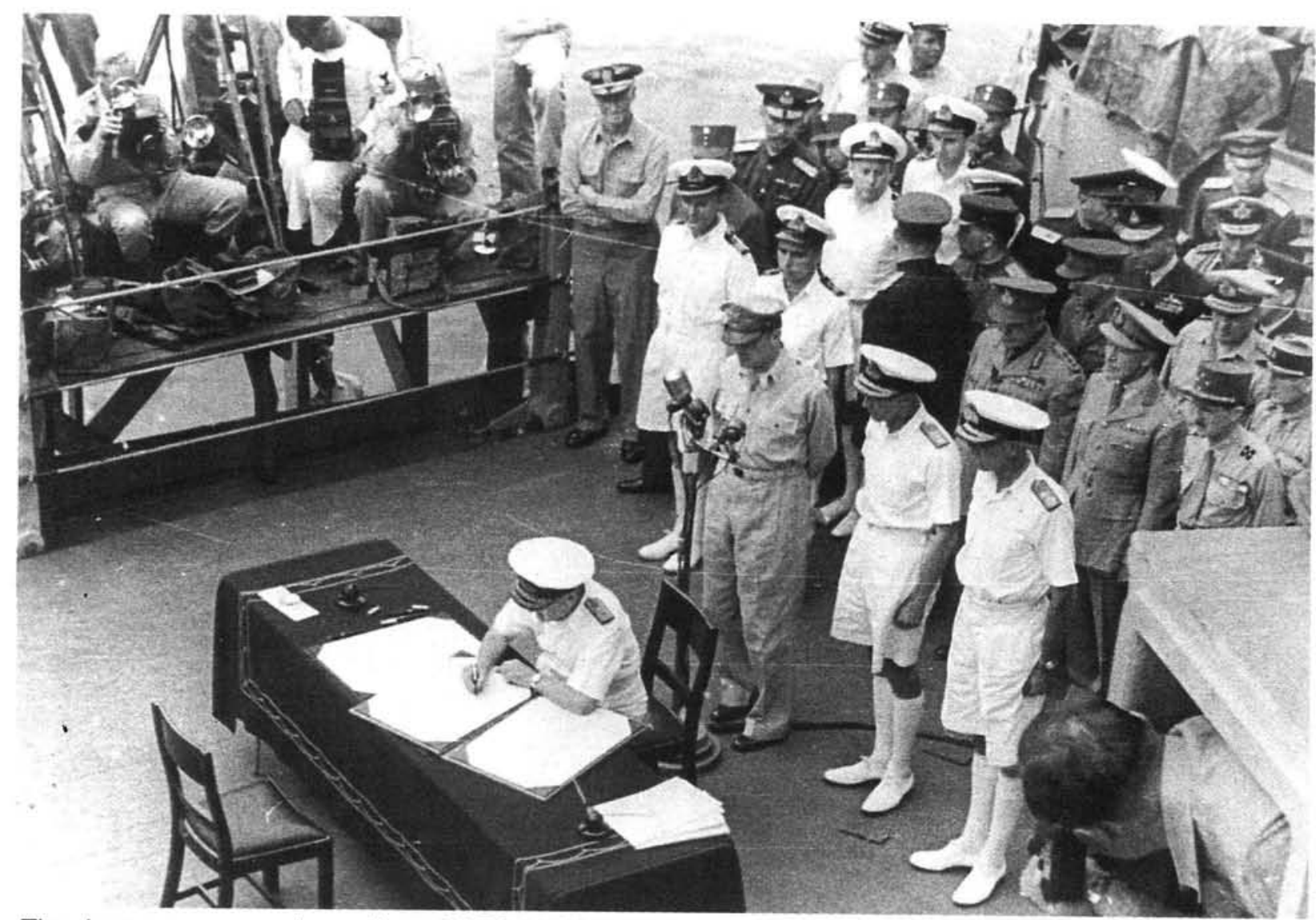

The Japanese surrender on board USS MISSOURI in Tokyo Bay on 2 September 1945. The SA Naval Forces were represented by Cdr A.P. Cartwright on the left of General Douglas MacArthur (behind the microphone). 